\title{
Signifikansi Larangan Operasi Plastik Dalam Penafsiran QS. An Nisa (4): 119 Perspektif Makna Cum Maghza
}

\author{
Azizah Kumalasari \\ Konsentrasi Studi Qur'an Hadis \\ UIN Sunan Kalijaga Yogyakarta \\ azizahkumalasari.ak@gmail.com
}

\begin{abstract}
Abstrak
Artikel ini mencoba untuk mengetahui signifikansi larangan operasi plastik dalam Qs. An Nisa (4): 119. Sebagaimana dalil ini digunakan untuk meligitimasi praktik operasi plastik dalam Al Qur'an, namun disisi lain eksistensinya yang semakin tren dikalangan masyarakat yang lebih dikenal dengan bedah kosmetik. Sehingga tidak ada titik temu antara dalil Al Qur'an dengan segala perkembangan penafsirannya dan fenomena bedah kosmetik ini. Penulis menggunakan metode tematik-analisis dengan teori hermeneutik Makna cum maghza dengan menitikberatkan pembahasan pada kalimat yang diteliti maknanya dan peninjauan terhadap asbabun nuzul makro dan mikro ketika ayat diturunkan. Sehingga dari pembacaan keduanya dapat mengambil signifikansi atau pesan utama dari Qs. An Nisa (4): 119. Hasil pembahasan artikel ini menemukan bahwa ayat ini mengedepankan kemaslahatan umat, dengan beberapa batasan yang perlu dipertimbangkan ketika melakukan operasi plastik. Antara lain; sesuai dengan kebutuhan, tidak merubah fungsi organ tubuh yang dioperasi dan tidak merugikan orang lain pada praktek transplantasi organ tubuh.
\end{abstract}

Kata Kunci : Signifikansi, Operasi Plastik, Makna Cum Maghza.

\section{Abstract}

This article tries to find out the significance of the plastic surgery ban in Qs. An Nisa (4): 119. As this proposition is used to legitimize the practice of plastic surgery in the Qur'an prespective, on the other hand, its axinstence is increasingly becoming a trend among the public, which is known as cosmetic surgery. So that there is no commond ground between the morals in the Qur'an with all the interpretations and the phenomenon of cosmetic surgery. The author uses a thematic-analysis method with the theory of hermeneutic Makna cum maghza with an emphasis on the discussion of the sentence being examined for its meaning and a review of the macro and micro of its asbabun nuzul when the verse is reveealed. So that from reading both of them can take the significance or the main massage from Qs. An Nisa (4): 119. The results of the discussion this verse puts forard the benefit of the whole people, with several limitation that need to be considered when doing plastic surgery. Such as; as needed, does not change the function of the operated organs and does not harm others in the practice of organ transplantation.

Keywords : Significance, Plastic Surgery, Makna Cum Maghza 


\section{Pendahuluan}

Salah satu tujuan operasi plastik adalah untuk memperindah bagian tubuh, baik dari bentuk yang jelek menjadi bagus atau dari bentuk yang sudah bagus menjadi lebih bagus. Namun praktik ini diharamkan dalam prespektif ilmu fikih, karena hal ini tidak sejalan dengan pesan Qs. At-Tin (95): 4 dimana Allah swt. menciptakan manusia dengan bentuk yang paling sempurna. Sehingga orang-orang yang melakukan operasi plastik ini dinilai tidak amanah dengan apa yang Allah swt. berikan atas dirinya sebagai seorang hamba. Bahkan dalam kutipan sebuah hadis yang diriwayatkan oleh Bukhari dari Abu Hurairah meriwayatkan bahwa Allah swt. akan melaknat bagi perempuan yang menyambung rambutnya, mentato, dan mencukur alisnya, baik pelaku yang meminta atau yang membantunya. ${ }^{1}$

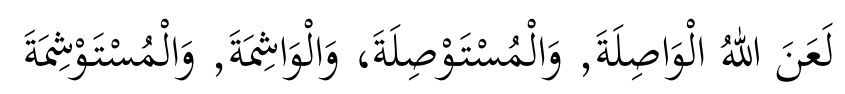

Allah melaknat perempuan yang menyambung rambutnya dengan rambut orang lain, dan orang yang membuat tato dan yang ditatonya, orang yang mengerik alis dan orang yang meminta dikerik alisnya.

Allah swt. berfirman Qs. An-Nisa (4):119:

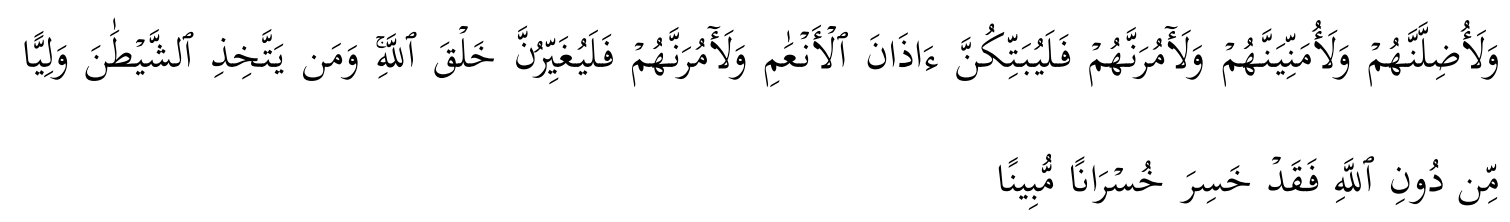

Dan aku sesatkan mereka dan akan aku timbulkan keinginannya yang salah dan aku perintahkan mereka memotong telinga-telinga ternak dan akan aku perintahkan mereka mengubah ciptaan Allah, siapa pun yang menjadikan setan sebagai pelindung selain Allah, dia betul-betul telah rugi yang nyata.

Hemat penulis kedua dalil diatas menjadi sia-sia karena pada realitanya praktik operasi plastik semakin menjadi tren dalam kehidupan masyarakat. Di sisi lain pemahaman hadis nabi dan Qs. An Nisa (4): 119 khususnya mengalami

\footnotetext{
${ }^{1}$ Al Imam Al Hafizh Abu Abdullah Muhammad bin Ismail al-Bukhari, Shahih Bukhari, (Jakarta: Pustaka As-Sunnah), 2010, hal. 122.
} 
stagnasi pada pemahaman yang cenderung literal dan belum menunjukkan pemahaman (penafsiran) yang merespon realita yang ada. Sehingga menurut ilmu kedokteran sah-sah saja jika sesuai dengan prosedur pelaksanaan operasi, bahkan jika operasi tersebut dianjurkan. Namun dari perspektif Al Qur'an dan hadis justru mengecam hal tersebut. Implikasinya semakin terpisah jauh antara realita berdasarkan perkembangan ilmu pengetahuan dan nilai spiritualitas dalam ayat-ayat $\mathrm{Al}$ Qur'an yang konon sebagai pedoman hidup umat manusia.

Penelitian Nurul Maghfiroh dan Heniyatun dalam Kajian Yuridis Operasi Plastik Sebagai Ijtihad Dalam Hukum Islam menyebutkan bahwa operasi plastik terdiri dari dua jenis menurut kondisi pasien, pertama, operasi plastik yang dilakukan pada penderita cacat fisik sehingga melalui operasi sel-sel tubuh dan jaringan-jaringan tubuh yang rusak dapat menjadi lebih baik. Kedua, operasi plastik yang bertujuan untuk memperindah bagian tubuh atau yang sering dikenal dengan bedah kosmetik. Contohnya memperbaiki bentuk hidung yang pesek menjadi mancung, membuat kelopak mata (double eyelid) dan lain sebagainya. Praktik yang kedua ini termasuk yang dilarang dalam Fikih merujuk pada Qs. An Nisa (4): 119. Sedangkan orang yang cacat contohnya penderita bibir sumbing yang mana bentuk mulut dan hidung menyatu, bukan dari bentuk mulut dan hidung yang normal. Sehingga dari segi sosial para penderita akan merasa tersisihkan akibat perbedaan tersebut. Maka diperbolehkannya melakukan operasi sebagai upaya untuk meminimalisir diskriminasi dan marjinalisasi dalam lingkungan masyarakat. ${ }^{2}$

Senada dengan penelitian Rabi'atul Adawiyah dan Izhar Ariff bahwa perubahan yang diperbolehkan adalah jika terdapat cacat pada bentuk fisik seseorang. Sedangkan yang dilarang adalah yang merubah bagian tubuh tanpa ada indikasi cacat sebelumnya, contohnya pada produk-produk kosmetik pemutih kulit yang terjual bebas di pasaran. Sehingga dalam penelitian ini mereka merumuskan 10 prinsip sebagai indikasi dibolehkannya merubah

\footnotetext{
${ }^{2}$ Nurul Maghfiroh dan Heniyatun, Kajian Yuridis Operasi Plastik Sebagai Ijtihad Dalam Hukum Islam, The $2^{\text {nd }}$ Univercity Research Coloquium 2015, hal. 120.
} 
ciptaan Allah swt.; 1) pengubahan bersifat sementara, 2) tidak ada unsur penipuan, 3) sesuai dengan syariat Islam, 4) bersih, suci, dan tidak membahayakan, 5) tidak menyerupai unsur agama lain, 6) merupakan keperluan yang mendesak, 7) dilakukan oleh dokter yang ahli dalam bidangnya, 8) yakin dengan keberhasilan selama perawatan, 9) mengutamakan batasan aurat, 10) bukan merupakan suatu hal yang mubazir. ${ }^{3}$

Adapun aspek lain yang ditunjukkan Shosh Ben Ari dalam "The Changing Attitude of Islam Toward Cosmetic Procedures And Plastic Surgery" bahwa operasi plastik yang dilakukan untuk mempercantik penampilan tidak diperbolehkan dalam hukum Islam. Merujuk pada Qs. An Nisa (4): 119 yang menyatakan bahwa merubah ciptaan Allah swt. merupakan salah satu ajakan setan. Bedah kosmetik dipandang sebagai hal yang tidak dibutuhkan, melainkan hanya sebuah produk modernisasi Barat. Beberapa faktor yang mendorong bedah kosmetik adalah tayangan televisi yang dalam film-film atau sinetron secara tidak langsung membentuk pengetahuan standard kecantikan pada sebuah wilayah, contohnya karakter Cinderella atau Barbie yang digambarkan sebagai kecantikan yang sempurna bagi seorang wanita. ${ }^{4}$ Hemat penulis ada pesan kesederhanaan yang disampaikan dalam artikel ini, melihat bahwa tidak murah biaya untuk melakukan operasi plastik.

Pada artikel ini penulis ingin menelusuri penafsiran Qs. An Nisa (4): 119 dengan menggunakan metode tematik ayat dan teori hermeneutika Makna cum maghza. Kajian pada satu tema dapat memfokuskan penulis dalam memahami penafsiran Qs. An Nisa (4): 119 secara khusus, tanpa membatasi penafsiran ayat-ayat lainnya yang setema dengan pembahasan larangan operasi plastik dalam Al Qur'an. Sedangkan teori hermeneutika Makna cum maghza memiliki andil bagaimana memahami penafsiran yang beragam antara satu dengan

\footnotetext{
${ }^{3}$ Rabiatul Adawiyah dan Izhar Ariff, Pemutihan Kulit Dalam Prinsip Mengubah Ciptaan Allah SWT, Fikiran Masyarakat, Vol. 6, No. 2, 2018, hal.65.

${ }^{4}$ Shosh Ben Ari, The Changing Attitude of Islam Toward Cosmetic Procedures And Plastic Surgery, Acta Orientalia Academiae Scientiarum Hungaricae, Vol. 66, No. 2, 2013, hal. 150.
} 
lainnya. Dengan memahami kalimat yughoyyir secara literal dan mengaitkan dengan konteks sosio-historis ketika ayat tersebut diturunkan.

Adapun masalah yang akan dianalisis dalam artikel ini adalah Bagaimana konteks sosio-historis ketika ayat tersebut diturunkan? Karena sudah dipastikan Al Qur'an merespon suatu kejadian, tidak diturunkan begitu saja dari tempat yang hampa sejarah. Dan apa pesan utama dari penafsiran Qs. An Nisa (4): 119 sebagai dalil yang melarang merubah bentuk tubuh manusia atau ciptaan Allah swt. pada kasus bedah kosmetik? Bagaimana batasan dalam merubahnya?

\section{Fenomena Operasi Plastik; Idealisasi Bentuk Tubuh Perempuan}

Operasi plastik (Plastic Surgery) adalah salah satu teknik pengobatan dengan cara mencangkok atau dikenal dengan transplantasi. Kata 'plastik' berasal dari bahasa Yunani yang berarti membuat atau mencetak. Kaitannya dengan transplantasi yaitu memperbaiki bagian tubuh yang rusak karena bawaan lahir, akibat virus atau perawatan tertentu, bahkan akibat kecelakaan. Kemudian dicangkokkan dengan jaringan pada bagian tubuh lainnya, seringkali dijumpai penggunaan tulang rawan telinga yang dicangkok pada batang hidung. 5

Praktik operasi plastik berawal dari bentuk apresiasi terhadap tentara yang telah berjuang di medan perang pada Perang Dunia Kedua. Mereka mendapatkan pelayanan dalam penyembuhan luka-luka ketika pertempuran, sehingga tubuh mereka dapat kembali normal, tanpa ada cacat yang mengganggu keseharian mereka. Berlanjut pada periode pasca perang dunia kedua, praktek operasi plastik dilakukan atas permintaan masyarakat Amerika Serikat terutama keturunan Yahudi dan Italia untuk dioperasi pada bagian hidung (rhinoplasty) agar terlihat lebih alami seperti masyarakat Amerika umumnya. Menurut Anthony Elliot bahwa beberapa pasien operasi plastik di

${ }^{5}$ A. B. Wallace, "The History And Evolution Of Plastic Surgery", Res Medica Journal of The Royal Medical Society, Vol. 4, No. 4, 1965, hal. 7. 
Asia juga mengalami hal yang sama agar lebih terlihat ideal seperti suku Kaukasia. 6

Beberapa klinik kecantikan di Indonesia misalnya menyediakan layanan untuk implan hidung (rhinoplasty), peremajaan kulit (facelifting), pembentukan rahang (jaw contour) dan masih banyak lainnya. Hal ini dilakukan untuk menangani pasien yang bermasalah dengan bagian tubuhnya tersebut, contohnya hidung pesek, rahang lebar, kelopak mata yang kecil, kantung mata, sampai dengan lemak tubuh yang berlebih, dengan prosedur operasi yang berbeda-beda. Bagi sebagian masyarakat bersikap kontra, cenderung memandangnya sebagai sesuatu yang berlebihan, karena umumnya operasi plastik hanya ditujukan bagi orang-orang yang cacat fisik.

Operasi plastik yang masih diperbincangkan di lingkungan masyarakat adalah bedah kosmetik. Bedah kosmetik sendiri termasuk jenis operasi ringan yang dilakukan pada bagian wajah dan tubuh untuk mendapatkan bentuk yang ideal. Antara lain: blepharoplasty, hidung (rhinoplasty), orthognathic surgery, dan face lifts pada wajah. Adapun praktik bedah dalam pembentukan bentuk tubuh seperti implan payudara (breast augmentation) dan pengencangan perut (tummy tuck). Jun Li, dkk menyimpulkan dalam penelitiannya "Predictive Factors For Cosmetic Surgery: A Hospital-Based Investigation" bahwa tiga teratas jenis bedah kosmetik yang paling banyak digemari pada masyarakat China pada tahun 2016 adalah operasi daerah mata seperti menghilangkan kantung mata, suntik botox dan nevus removal (penghilangan tahi lalat atau tanda lahir atau bintik hitam) yang bagi sebagian orang merasa terganggu dengannya. ${ }^{7}$

\footnotetext{
${ }^{6}$ Nicola R. Dean, dkk, "Defining Cosmetic Surgery", Australian Journal Of Plastic Surgery, Vol. 1. No. 1. 2018, hal 117. Sekilas A.B. Wallace dalam "The History And Evolution Of Plastic Surgery" memaparkan secara singkat tentang evolusi operasi plastik yang awalnya dikenal dengan transplantasi. Berawal dari tindakan penyembuhan bagi tentara perang yang umumnya terluka pada bagian hidung yang mana penyembuhannya dilakukan dengan mengambil jaringan tubuh lain pada diri sendiri. Hingga tindakan serakah mengambil bagian tubuh lain dari manusia di luar dirinya yang dilakukan oleh beberapa Kaisar Romawi pada abad-14. Sengaja memutilasi lawan atau tawanan ketika perang untuk melengkapi bagian tubuh mereka yang hilang dalam proses penyembuhannya, dimana tindakan ini justru mengorbankan hak manusia untuk kepentingan individu.

7 Jun Li, dkk, "Predictive Factors For Cosmetic Surgery: A Hospital-Based Investigation" diakses pada 19 nopember 2019 pada Springer Plus, hal. 2.
} 
Beberapa alasan pasien dalam menjalankan bedah kosmetik dipengaruhi oleh penilaian masyarakat terhadap fisik mereka. Salah satunya terlihat pada penelitian Dolatshahi yang dikutip Jun Li, dkk bahwa bedah kosmetik yang dilakukan masyarakat Korea Selatan adalah agar lebih terlihat menarik secara fisik dan penampilan untuk membedakan mereka dengan yang lainnya. Sehingga dapat menunjang mereka dalam dunia pekerjaan, hubungan keluarga, dan hubungan sosial. Selain itu juga didorong oleh publik figur Korea Selatan yang tidak jarang melakukan bedah kosmetik, berpengaruh pada masyarakat terutama kaum wanita bahwa untuk menjadi lebih cantik dapat melalui bedah kosmetik. ${ }^{8}$

Nicola, dkk mengutip dari Morgan dan Bordo, bahwa diskursus bedah kosmetik berkembang di kalangan patriarki. Berbagai macam bentuk tubuh ideal seorang wanita di publik yang terbentuk oleh angan-angan laki-laki mempengaruhi para wanita untuk melakukan bedah kosmetik ini. Hal ini mutlak terjadi dalam kehidupan manusia yang bercampur antara laki-laki dan perempuan, dan agaknya menimbulkan ketimpangan. Lebih jauh Nicola, dkk juga merujuk pada penelitian Davis yang menunjukkan bahwa pergeseran budaya patriarki ini terlihat dari keterlibatan perempuan dalam dunia pendidikan, juga berpengaruh terhadap motivasi perempuan dalam melakukan bedah kosmetik. Motivasi tersebut berkembang dari sekedar memperindah tubuh akibat penagaruh sosial menjadi sebuah penghargaan terhadap diri sendiri setelah bekerja keras, kemudian mewujudkannya dalam bedah kosmetik. $^{9}$

Shosh Ben Ari dalam "The Changing Attitude of Islam Toward Cosmetic Procedures And Plastic Surgery" menyinggung tentang standard kecantikan seorang perempuan Arab pada masa Jahiliyah yang cantik secara alami tanpa berbagai macam polesan produk make up. Hal ini juga ditunjukkan pada beberapa hadis yang menjelaskan bahwa diperbolehkannya mencukur rambut

\footnotetext{
${ }^{8}$ Ibid. Hal. 4.

${ }^{9}$ Nicola R. Dean, dkk, "Defining Cosmetic Surgery".... hal. 117.
} 
di beberapa bagian tubuh dan larangan mewarnai rambut. Jauh dari zaman Nabi saw. modernisasi dan globalisasi justru menawarkan cara untuk menjadi cantik dengan munculnya berbagai macam industri produk make up dan metode operasi plastik. Shosh mengutip dari Yusuf Qardhawi bahwa praktik operasi plastik diperbolehkan atas dasar kepentingan kesejahteraan masyarakat kolektif maupun individu. Dari sinilah operasi plastik diperbolehkan dalam hukum Islam atas dasar manfaat yang diberikan setelah operasi plastik, bukan dipandang sebuah kemewahan. ${ }^{10}$

Selain daripada contoh bedah kosmetik diatas, adapun produk make up (tata rias) dan skincare (perawatan tubuh) yang juga diperuntukkan memperindah bagian tubuh, terutama bagian wajah. Beberapa produk make up dan skincare ini pun dijual bebas dipasaran dengan harga yang beragam dari yang terjangkau hingga produk-produk premium yang jauh lebih mahal. Berbeda dengan bedah kosmetik, make up dan skincare hanya memberikan efek sementara karena penggunaan make up dapat dihapus dengan mencuci muka atau bagian tubuh yang terkena make up tersebut. Sedangkan skincare memberikan efek lebih baik daripada sebelumnya sesuai dengan perawatan yang dilakukan pada tubuh secara rutin, namun jika pemakaian dihentikan maka bagian tubuh yang dirawat tersebut akan kembali seperti semula, kecuali jika terdapat perubahan dalam beberapa faktor, seperti usia dan hormon seseorang, keduanya bekerja lebih banyak pada tampilan luar kulit.

\section{Teori Hermeneutika Makna Cum Maghza; Pengembangan Baru Kontekstualisasi Ayat-Ayat Al-Qur'an}

Teori hermeneutika Makna cum maghza merupakan teori pembacaan teks yang menawarkan kerja seimbang antara memahami ayat secara literal dan pesan utama (signifikansi) sebuah ayat. Dimana satu ayat merupakan gabungan antara kosakata-kosakata Arab yang digunakan sebagai simbol untuk menunjukkan sebuah peristiwa atau suatu benda ketika ayat tertentu

\footnotetext{
${ }^{10}$ Shosh Ben Ari, The Changing Attitude Of Islam Toward Cosmetic Procedures..., hal. 147.
} 
diwahyukan. Kemudian dipahami atau ditafsirkan oleh masing-masing ulama dan peneliti dari berbagai generasi, yang menghasilkan kemajemukan penafsiran ayat dan signifikansinya yang cenderung dinamis, dibanding dengan ayat Al-Qur'an yang statis semenjak abad ke-7 M. Sehingga produk penafsiran yang dihasilkan pun beragam dan relatif karena merupakan elaborasi antara wawasan teks dan wawasan subjektif peneliti atau mufassir yang juga dipengaruhi oleh kondisi sosial dan keilmuwannya bahkan tidak jarang dipengaruhi oleh ideologi dan kepentingan pribadi. ${ }^{11}$

Adapun tiga langkah utama dalam teori ini, antara lain: kajian linguistik, kajian sosio-historis makro maupun mikro dan menganalisa signifikansi dari ayat tersebut. Pertama, kajian linguistik yang dilakukan dengan intratekstualis pada spesifik kata yang diteliti untuk melihat perbandingan konsep/istilah yang digunakan dalam Al-Qur'an. Hal ini ditujukan untuk melihat dinamika konsep/istilah dalam Al-Qur'an atas kosakata tertentu. ${ }^{12}$ Pada artikel ini akan mengkaji kata yugoyyir dalam Al-Qur'an untuk lebih lanjut menganalisa dan membandingkan antar ayat yang menggunakan kosakata tersebut.

Kedua, mengkaji konteks sosio-historis makro dan mikro pada saat ayat diwahyukan. Ketiga, mencermati dan menganalisa dari data-data tersebut untuk menggali signifikansi ayat dan menghubungkannya dengan konteks kekinian. Hal ini dapat dilakukan dengan mempertimbangkan pandanganpandangan ulama klasik hingga kontemporer untuk mendapatkan pemahaman yang lebih komprehensif. ${ }^{13}$

\section{Penafsiran QS. An Nisa ayat 119}

\section{Gambaran Umum QS. An Nisa ayat 119}

\footnotetext{
11 Sahiron Syamsuddin, Hermeneutika Dan Pengembangan Ulumul Qur'an, (Yogyakarta: Naasea Press), 2017, hal. 140-141.

12 Sahiron Syamsuddin menambahkan untuk mengkaji secara sintagmatik dan paradigmatik, serta mengkaji sumer lain diluar Al-Qur'an, seperti hadis Nabi saw., puisi Arab, teks-teks israiliyyat, dan lain sebagainya yang bersangkutan dengan kosakata tertentu yang diteliti, namun "bila diperlukan". Baca Sahiron Syamsuddin, Hermeneutika Dan Pengembangan Ulumul Qur'an..., hal. 142.

${ }^{13}$ Ibid. Hal. 143.
} 
Allah swt. berfirman :

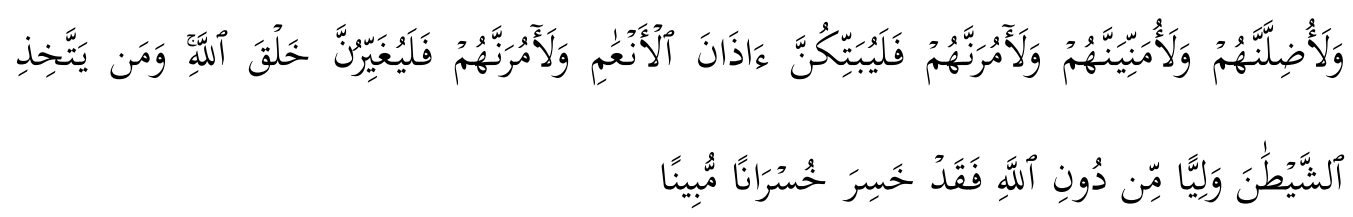

Dan aku sesatkan mereka dan akan aku timbulkan keinginannya yang salah dan aku perintahkan mereka memotong telinga-telinga ternak dan akan aku perintahkan mereka mengubah ciptaan Allah, siapa pun yang menjadikan setan sebagai pelindung selain Allah, dia betul-betul telah rugi yang nyata.

Sekilas dalam ayat tersebut merupakan informasi bahwa setan akan mengajak manusia untuk mengubah ciptaan Allah swt. dengan cara memotong telinga hewan ternak. At-Thabari menafsirkan dari beberapa riwayat sahabat yang dimaksud dengan mengubah ciptaan Allah swt. disini yakni tentang pengebirian hewan yang sering terjadi di masyarakat Jahiliyah ketika itu. ${ }^{14}$ Berbeda dengan penafsiran Quraish Shihab tentang ayat ini bahwa tidak ada larangan atas praktek operasi plastik sekali pun dalam ayat ini, karena esensiya bahwa operasi plastik adalah usaha untuk memperbaiki bukan merubah fungsi organ tubuh atau anatomi tubuh. ${ }^{15}$

Ayat ini sekilas tidak menunjukkan indikasi sebagai ayat larangan untuk operasi plastik yang termasuk dalam term yughoyyir

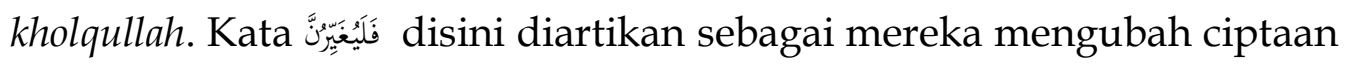
Allah swt. yakni merubah menjadi sesuatu yang baru sehingga terlihat

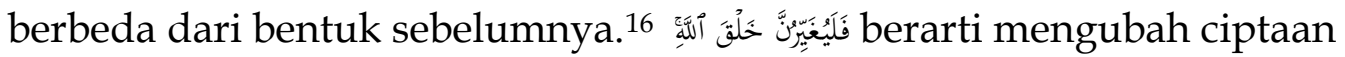
Allah swt. menjadi sesuatu yang berbeda dari sebelumnya. Contoh sederhana yang sering dijumpai yakni pada kasus bibir sumbing (cleft

${ }^{14}$ Abu Ja'far bin Muhammad at-Thabari, Tafsir at-Thabari, (Jakarta: Pustaka Azzam, 2009), jilid 7, hal. 749-753.

15 M. Quraish Shibah, Tafsir Al-Misbah Pesan, Kesan Dan Keserasian al-Qur'an, jilid 2, (Jakarta: Lentera Hati) 2016, hal. 724

16 Abul Fadal Jamaluddin Muhammad bin Makram bin Manzur al-Afriqi al-Misri, Lisan alArab, Jilid 15, (Beirut: Darul Kutub Al-Ilmiyah) 2009, hal. 47. 
lip) cacat bawaan lahir dimana mulut bagian atas terbelah menyatu dengan cuping hidung, melalui operasi plastik dirubah menjadi bentuk normal bibir dan hidung pada umumnya. Dalam hal ini praktek operasi plastik digunakan untuk merubah menjadi bentuk hidung dan mulut yang lebih baik dan sesuai dengan fungsi utamanya untuk bernafas dan makan.

Pada kosakata terdapat hanya pada satu ayat. Ayat ini sering dikutip dalam artikel-artikel online maupun artikel akademik sebagai landasan larangan praktek operasi plastik. Didukung pula dengan hadis yang diriwayatkan Bukhari, dari Abu Hurairah; 17

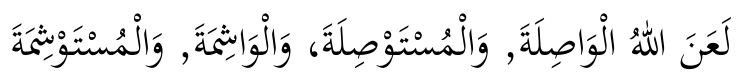

Allah melaknat perempuan yang menyambung rambutnya dengan rambut orang lain, dan orang yang membuat tato dan yang ditatonya, orang yang mengerik alis dan orang yang meminta dikerik alisnya.

Wacana yang dibangun berdasarkan hadis tersebut secara tekstual tertuju pada perempuan sebagai pelakunya yang melakukan perubahan fisik seperti yang disebutkan. Hal ini terlihat pada kosakatakosakata yang digunakan adalah ism muannas diakhiri dengan huruf $t a^{\prime}$ marbuthoh, yang memang menunjukkan gendernya sebagai kosakata perempuan. Sehingga berimplikasi pada penafsirannya seakan-akan Allah swt. hanya melaknat perempuan yang merubah fisiknya seperti yang disebutkan dalam hadis tersebut.

Agar lebih valid dalam melegitimasi hukum operasi plastik dalam Islam, kemudian beberapa artikel online tersebut mengutip QS. AnNisa ayat 119. atas pengharaman operasi plastik. Pengharaman operasi plastik ini ditekankan pada tujuannya untuk mempercantik bentuk tubuh, seperti bentuk hidung, rahang, kelopak mata, bibir, bentuk

${ }^{17} \mathrm{Al}$ Imam Al Hafizh Abu Abdullah Muhammad bin Ismail al-Bukhari, Shahih Bukhari, (Jakarta: Pustaka As-Sunnah), 2010, hal. 122. 
tubuh, bahkan bentuk payudara, dan lain sebagainya. Kemudian yang melakukan operasi plastik dinilai kurang, bahkan tidak bersyukur dengan apa yang sudah diberikan oleh Allah swt. dan dianggap hanya mengikuti hawa nafsu semata. ${ }^{18}$

\section{Konteks Makro Dan Mikro Qs. An-Nisa ayat 119}

Secara eksplisit ayat ini tidak diriwayatkan berdasarkan narasi apapun sebagai indikasi makro diturunkannya kepada Nabi Muhammad saw. Al Bagawiy menjelaskan bahwa konteks ayat ini diturunkan merespon masyarakat Arab Mekah penyembah berhala Latta, Uzza dan Manat atas Qs. An Nisa (4): 117. Bahwa ada orang tua yang menghampiri Rasulullah saw. dan bertanya apakah Allah swt. akan mengampuninya setelah ia berangan-angan melarikan diri dari Allah swt. atas dosa-dosa yang ia lakukan?19. Kemudian pada potongan awal ayat 119 menyebutkan perkataan setan yang menggoda manusia termasuk diantaranya memberikan angan-angan kosong dan memerintahkan manusia untuk merubah ciptaan Allah swt.

\section{Intertektualis Dan Penafsiran Kalimat Yughoyyir Dalam Qs. An-Nisa} (4): 119

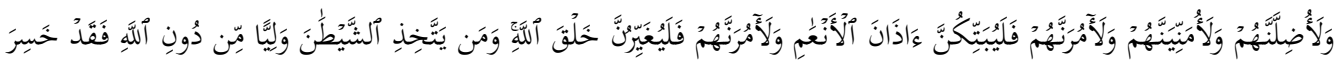

Qs. An-Nisa (4): 119 年

Dan aku sesatkan mereka dan akan aku timbulkan keinginannya yang salah dan aku perintahkan mereka memotong telinga-telinga ternak dan akan aku perintahkan mereka mengubah ciptaan Allah, siapa pun yang menjadikan setan sebagai pelindung selain Allah, dia betul-betul telah rugi yang nyata.

Potongan awal ayat "Dan aku sesatkan mereka dan akan aku timbulkan keinginannya yang salah dan aku perintahkan mereka memotong telinga-telinga ternak dan akan aku perintahkan mereka mengubah ciptaan

18 Beberapa website yang mendeskripsikan tentang hukum operasi plastik dalam Islam berdasarkan pencarian di www.Google.com dengan kata kunci “Operasi Plastik Dalam Islam".

${ }_{19}$ Abu Muhammad al-Husain bin Mas'ud Al Bagawiy, Ma'alim At Tanzil, jilid 2, Cet.IV, (t.tp: Dar Thibah li an-Nasyr wa at-Tawzi'), 1997, hal 289. 
Allah" berhubungan dengan ayat sebelumnya Qs. An-Nisa (4): 117 dan 118 (yang dilaknati Allah dan syaitan itu mengatakan: "Saya benar-benar akan mengambil dari hamba-hamba Engkau bagian yang sudah ditentukan (untuk saya)). Pada ayat 117 akan didapati konteks yang menunjukkan respon Al Qur'an atas masyarakat Arab penyembah berhala Latta, Uzza dan Manat di Mekah. ${ }^{20}$ Kemudian pada potongan ayat terakhir menunjukkan akibat menyembah kepada selain Allah swt. yaitu "siapa pun yang menjadikan setan sebagai pelindung selain Allah, dia betul-betul telah rugi yang nyata".

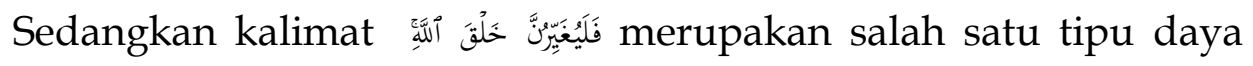
setan terhadap manusia yang memberikan angan-angan kosong. Kata

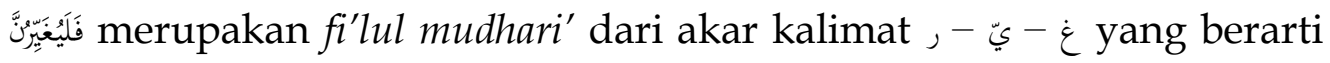
merubah, menggantinya dengan sesuatu yang berbeda. Ibnu A'rabi mencontohkan bahwa seseorang akan pergi melakukan perjalanan dengan unta yang lain, sedang unta yang digunakan ketika datang sebelumnya diistirahatkan. Sehingga terlihat ada dua unta yang berbeda keadaanya, satu unta yang masih sehat ditunggangi saat pergi dan unta lainnya yang sudah melakukan perjalanan sebelumnya. ${ }^{21}$

At Thabari mengutip beberapa riwayat yang membahas tentang

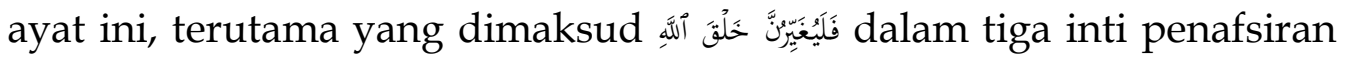
yang berbeda; tentang pengebirian terhadap hewan liar yang terjadi pada zaman Nabi saw., perubahan fitrah manusia yaitu merubah agama Allah swt. dan tentang merubah bentuk tubuh asli dengan mencukur alis, memberikan tato dan lain sebagainya. Riwayat dari Ibnu Abbas, Anas bin Malik, Syahr bin Hausyah, Ikrimah dan ar-Rabi' bin Anas bahwa yang dimaksud memotong bagian tubuh hewan disini

${ }^{20}$ Demikian pula dijelaskan sebelumnya Al Bagawiy juga mengutip demikian. Abu Ja'far bin Muhammad at-Thabari, Tafsir at-Thabari, jilid 7..., hal. 742.

${ }^{21}$ Abul Fadal Jamaluddin Muhammad bin Makram bin Manzur al-Afriqi al-Misri, Lisanul Arab, Jilid V,..., hal. 40 . 
adalah praktek pengebirian pada hewan yang terjadi di masa Nabi saw. yang dilakukan tanpa sebab pada bagian tubuh tertentu hewan. ${ }^{22}$

Al Bagawiy menambahkan bahwa Allah swt. menciptakan hewan untuk dikendarai dan untuk dimakan. Namun suatu ketika hal ini dilarang, justru hewan hanya disakiti dengan cara dikebiri. Selain itu matahari, bulan, batu dan benda mati lainnya diciptakan Allah swt. untuk diambil manfaatnya bukan untuk disembah. Demikian yang dimaksud dengan merubah ciptaan Allah swt. adalah merubah fungsinya sebagai sesuatu yang lain. ${ }^{23}$

Al Alusy menjelaskan tentang salah satu praktek pengebirian yang disinggung sebelumnya yang terjadi pada unta. Ketika satu unta melahirkan lima anak unta dan yang kelima adalah jantan. Induk unta ini kemudian dipotong telinganya, tidak dikendarai lagi, tidak dibawa kemanapun dan tidak digunakan untuk apapun. Pada awalnya induk unta ini dihalalkan untuk digunakan kemudian dilarang karena suatu hal yang tidak dapat diduga. Beliau juga menyinggung tentang khitan dan tato yang menurutnya tidak masalah jika dilakukan sesuai dengan kebutuhan, termasuk diantaranya merubah warna kulit, warna rambut dan lain sebagainya secara permanen, seperti pada penggunaan hena dan segala sesuatu yang dapat merubah bentuk aslinya ketika akan menghadapi perang untuk mengelabui musuh. ${ }^{24}$

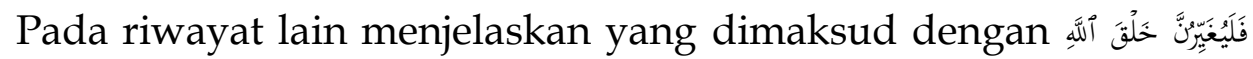
yakni perubahan agama Allah dengan menciptakan kebohongan dalam agama Allah. Dari penafsiran ini at-Thabari mengutip dari beberapa riwayat Ibnu Abbas, Ibrahim, al-Qasim bin al-Bazzah, Ikrimah, Mujahid, Qatadah, Ubaid bin Sulaiman, Qais bin Muslim, adh-Dhahak

\footnotetext{
${ }^{22}$ Abu Ja'far bin Muhammad at-Thabari, Tafsir at-Thabari, jilid 7,... hal. 749-753.

23 Abu Muhammad al-Husain bin Mas'ud Al Bagawiy, Ma'alim At Tanzil, jilid 2, Cet.IV, (t.tp: Dar Thibah li an-Nasyr wa at-Tawzi'), 1997, hal 289.

${ }^{24}$ Abu al-Fadl Syihāb al-Din al-Sayyid Mahmud Afandi al-Alusi Al-Bagdadi, Ruh al Ma'ani fi Tafsir al Qur' an al 'Azim wa al Sab'u al Matsani, Jilid 4 (Beirut: Dar al-Kutub al-ilmiyah, 2001), hal 285.
} 
bin Mazahim dan as-Suddi, sepakat bahwa yang dimaksud dengan i adalah agama Allah. Setan mengajak manusia untuk berpaling dari agama Allah dengan menjanjikan angan-angan agar manusia menyembah setan dan berhala serta meminta perlindungan dari setan, termasuk diantaranya mengharamkan yang halal dan menghalalkan yang haram. ${ }^{25}$

Al-Hasan menafsirkan خَلَقَ أنَّهِ sebagai membuat tato. Al-Hasan ditanyai perihal wanita yang mengoperasi wajahnya, ia berkata wanita itu akan mendapatkan kutukan dari Allah swt. karena telah mengubah ciptaan Allah swt. Berbeda dengan riwayat al-A'masy dari Ibrahim dari Abdullah bahwa Allah melaknat orang yang merapikan gigi, mencabut rambut alis, dan mentato tubuhnya karena hal ini adalah merubah ciptaan Allah swt. ${ }^{26}$

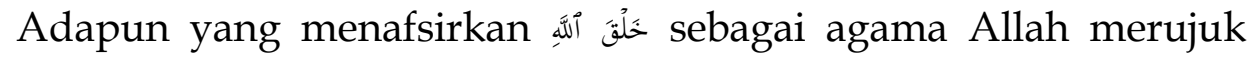
pada QS. Ar-Rum ayat 30 yang menjelaskan bahwa Allah swt. menciptakan manusia dengan fitrah Allah swt. barangsiapa yang merubah, berpaling dari fitrah tersebut maka sesungguhnya ia sudah berpaling dari agama Allah swt. Segala sesuatu yang bertentang dari fitrah Allah dinilai sebagai sesuatu yang haram termasuk diantaranya merubah ciptaan Allah swt. dengan operasi transgender. ${ }^{27}$

Perihal mengubah ciptaan Allah swt. salah satunya dengan memotong bagian tubuh hewan tertentu. Tujuannya untuk dipersembahkan kepada berhala-berhala mereka kaum Jahiliyah, dengan melukai bagian tubuh tertentu hewan ternak, seperti memotong telinganya, menusuk mata, memberi tato sebagai hiasan, dan lain sebagainya. Namun perilaku yang demikian cenderung menyakiti hewan ternak dan memperburuk fungsi anggota tubuh

\footnotetext{
${ }^{25}$ Abu Ja'far bin Muhammad at-Thabari, Tafsir at-Thabari, jilid 7,.... hal. 753-757.

${ }^{26}$ Abu Ja'far bin Muhammad at-Thabari, Tafsir at-Thabari, jilid 7,.... hal. 759-761.

${ }^{27}$ M. Quraish Shibah, Tafsir Al-Misbah Pesan, jilid 2...., hal. 724.
} 
hewan, seperti matanya yang ditusuk mengakibatkan terganggunya penglihatan hewan tersebut atau dengan memberikan tato sebagai hiasan pada tubuh hewan dengan cara melukai dengan membakar bagian tubuh tertentu. ${ }^{28}$

Contoh lain yang termasuk dalam kategori mengubah ciptaan Allah swt. adalah menggunakan yang tidak sesuai dengan fungsinya. Seperti mempertuhankan bintang dengan mengundi nasib dan menggunakan fenomena gerhana matahari atau bulan menjadi sebuah pertanda peristiwa tertentu. Termasuk diantaranya pengebirian hewan, homoseksual, dan lesbian sebagai perilaku yang menyimpang tidak sesuai dengan fitrah manusia. ${ }^{29}$

Adapun riwayat hadis dari Abu Dawud tentang hidung sahabat yang terpotong akibat perang: ${ }^{30}$

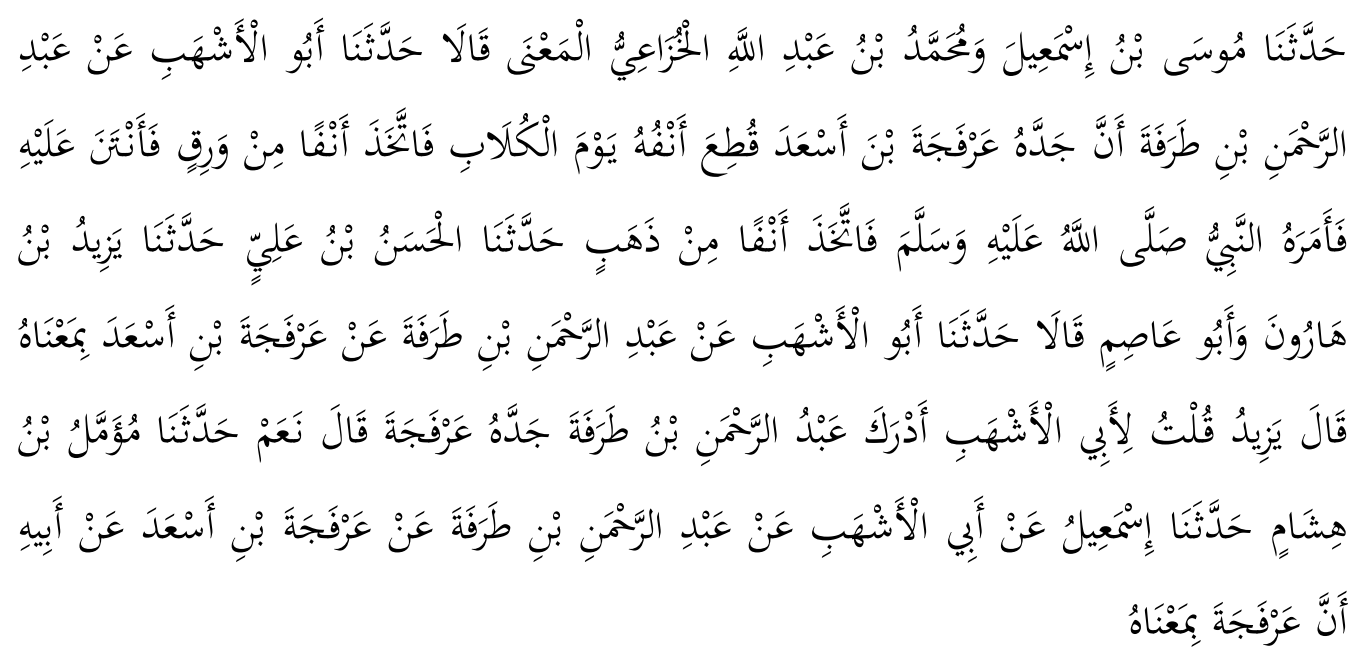

"Telah menceritakan kepada kami Musa bin Isma'il dan Muhammad bin Abdullah Al Khuza'i keduanya berkata; telah menceritakan kepada kami Abu Al Asyhab dari 'Abdurrahman bin Tharafah bahwa kakeknya Arfajah bin As'ad, hidungnya terpotong saat perang Al Kilab. Lalu ia membuat hidung palsu dari perak, tetapi justru hidungnya menjadi busuk. Nabi shallallahu 'alaihi wasallam lalu memerintahkan kepadanya (untuk membuat hidung dari

${ }^{28}$ Ibid.
${ }^{29}$ Ibid.
${ }^{30}$ Hadis ini juga diriwayatkan oleh Tirmidzi, Nasa'i dan Ahmad bin Hanbal. Syihabuddin Ahmad bin Husain bin Hasan bin Ali bin Yusuf bin Ali bin Arsilan ar-Ramli asy-Syafi'I, Syarh Sunan Abu Dawud Li Ibnu Roslan, Jilid 16, (Damaskus: Darul Falah), 2016, hal. 624. 
emas), hingga ia pun membuat hidung dari emas." Telah menceritakan kepada kami Al Hasan bin Ali berkata, telah menceritakan kepada kami Yazid bin Harun dan Abu Ashim keduanya berkata; telah menceritakan kepada kami Abu Al Asyhab dari 'Abdurrahman bin Tharafah dari Arfajah bin As'ad dengan makna yang sama. Yazid berkata, "Aku berkata kepada Abu Al Asyhab, "Apakah 'Abdurrahman bin Tharafah mendapati kakeknya, Arfajah?" Ia menjawab, "Ya." Telah menceritakan kepada kami Muammal bin Hisyam berkata, telah menceritakan kepada kami Isma'il dari Abu Al Asyhab dari 'Abdurrahman bin Tharafah dari Arfajah bin As'ad dari Bapaknya bahwa Arfajah .... dengan makna yang sama."

Nabi Muhammad saw. mengizinkan Arfajah bin As'ad menggantikan hidungnya dengan emas agar tidak menimbulkan sakit yang lebih parah, karena sebelumnya pada hadis tersebut menceritakan keadaan hidungnya yang busuk ketika diganti dengan perak. ${ }^{31}$ Demikian hadis ini mengisayaratkan kemaslahan umat baik individu atau secara kolektif sesuai dengan kebutuhan, tanpa membahayakan salah satu diantaranya. Hal ini juga terdapat dalam praktek transplantasi organ tubuh, tidak ada yang dirugikan antara pihak pendonor dan penerima karena keduanya menyetujui untuk berbagi, pendonor sehat tanpa kekurangan kebutuhan atas organ tubuhnya dan kondisi penerima juga membaik atas bantuan organ dari pendonor tersebut. ${ }^{32}$

\section{Signifikansi Dan Kontekstualisasi Penafsiran Qs. An Nisa (4): 119}

Berdasarkan telaah beberapa penafsiran para ulama atas Qs. An-Nisa (4)

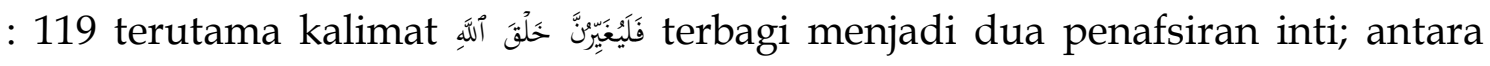
yang menafsirkan sebagai agama Allah swt. dan yang terkait dengan perubahan atau pengrusakan fisik makhluk hidup ciptaan Allah swt. Perubahan yang terjadi pada agama Allah swt. adalah salah satu perintah setan agar manusia menghalalkan yang haram dan mengharamkan yang halal,

\footnotetext{
${ }^{31}$ Ibid. Hal. 625.

${ }^{32}$ Lailatu Rohmah, Kontekstualisasi Hadis Tentang Transplantasi, Jurnal Hikmah, Vol. XIV,
} No. 2, 2018, hal. 128. 
sehingga manusia dapat pula mengerjakan segala larangan Allah swt. dan menjauhi perintah Allah swt. Sedangkan perubahan pada fisik makhluk hidup adalah yang berkaitan dengan pengebirian hewan dan segala macam bentuk perubahan pada manusia, seperti yang banyak dicontohkan pada wanita; operasi plastik, mencukur alis, mentato, dan lain sebagainya.

Pada penafsiran inti kedua ini yang masih banyak diperbincangkan, karena seiring berjalannya waktu dan perkembangan zaman, banyak praktek yang menunjukkan merubah ciptaan Allah swt. khususnya operasi plastik. Umumnya larangan operasi plastik terfokus pada perubahan yang terjadi pada bentuk tubuh luar dan bercampur dengan asumsi orang lain yang melihat perubahan pada tubuh seseorang. Beberapa data yang menunjukkan motivasi pelaku operasi plastik diatas justru hanya menyebutkan sebagai penghargaan untuk diri sendiri. Namun tidak menutup kemungkinan bahwa motivasi itu terbentuk dari konteks patriarkhi yang mendorong para wanita agar selalu terlihat cantik, baik dengan cara instan ataupun dengan perawatan.

Signifikansi dari penafsiran Qs. An Nisa (4): 119 yang dikemukakan oleh para ulama agar berhati-hati mengontrol hawa nafsu yang bisa datang dari lingkungan sekitar. Salah satunya angan-angan kosong yang timbul akibat hasutan, dorongan yang menjadi sebuah motivasi, ambisi diluar dari

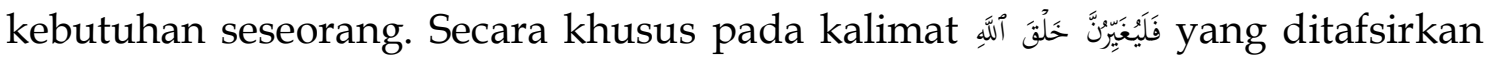
sebagai merubah bentuk fisik manusia cenderung identik dengan perempuan yang hanya mengikuti hawa nafsu semata agar selalu terlihat cantik.

Adapun batasan yang perlu dilihat agar tidak berlebihan untuk menggunakan make up, skincare atau operasi plastik. Pertama, sesuai dengan kebutuhan; make up dan skincare adalah perawatan yang sering dilakukan oleh perempuan agar terlihat cantik. Sebaiknya hanya dilakukan sesuai dengan kebutuhan, baik dari penggunaan make up di wajah yang sesuai dengan tempat dan kondisi saat digunakan, dari produk yang digunakan pun disesuaikan dengan kemampuan untuk membelinya dari harga murah sampai 
yang mahal, membeli satu macam produk lipstik atau lebih tidak dipermasalahkan asal sesuai dengan kebutuhan. Tentu kebutuhan mahasiswa berbeda dengan kebutuhan make up artis (MUA) yang notabene adalah pekerjaan untuk merias orang lain. Begitu pula dengan penggunaan skincare, disesuaikan dengan jenis kulit dan keuangannya. Jika hanya mampu untuk menggunakan pembersih wajah dan pelembab saja cukup, tidak perlu memaksakan diri untuk membeli produk skincare mengikuti "7 steps" ala korea yang memang produk-produknya tidak terjangkau. Begitu pula dengan operasi plastik, pada dasarnya operasi plastik adalah melakukan tindakan medis pada bagian tubuh tertentu yang dirasa mengganggu. Jadi wajar saja mungkin publik figur cenderung kerjaannya adlah menghibur, untuk melakukan operasi plastik untuk mengurangi gangguan yang membuatnya repot. Tentu didasari juga dengan penyesuaian kebutuhan.

Kedua, tidak merubah fungsinya. Baik make up, skincare dan operasi plastik yakni masih digunakan sesuai dengan porsinya. Contohnya pada operasi plastik yang tujuan medisnya untuk memperbaiki sel atau jaringan yang rusak. Beberapa pelaku operasi plastik terlalu obsesi dengan perubahan bentuk fisik secara ideal dan lebih sempurna, namun hal itu tidak merubah fungsi organ tubuh atau bentuk anatomi tubuh. Namun yang perlu diukur kembali adalah penyesuaian kebutuhan seseorang.

Ketiga, tidak merugikan pihak lain atau mengutamakan kemaslahatan bersama, hal ini lebih ditekankan pada praktek transplantasi tubuh. Ikhlas antara pendonor dan penerima sehingga organ tubuh yang digunakan dapat berfungsi dengan baik, selain ditinjau dari beberapa pemeriksaan kesehatan dari pihak medis antara kedua belah pihak.

\section{Kesimpulan}

Uraian beberapa penafsiran diatas dapat disimpulkan bahwa ayat ini diturunkan dalam konteks masyarakat Arab pagan Mekah penyembah berhala 
spesifik pada Qs. An Nisa (4):117. Mereka menyembah benda mati yang tidak memberikan apapun selain jika digunakan dalam kehidupan sehari hari, seperti menyembah berhala Latta, Uzza, Manat dan diantaranya juga menyembah matahari, bulan dan batu. Tidak lain menyembah berhala berarti menyembah setan yang durhaka (Qs. An Nisa (4): 118), setan mengatakan “Dan aku sesatkan mereka dan akan aku timbulkan keinginannya yang salah dan aku perintahkan mereka memotong telinga-telinga ternak dan akan aku perintahkan mereka mengubah ciptaan Allah" (Qs. An Nisa (4):119).

Hemat penulis beberapa penafsiran diatas sedikitnya yang menafsirkan tentang merubah ciptaan Allah swt. dengan cara operasi plastik. Namun ada beberapa batasan dalam larangan merubah ciptaan Allah swt. terkait perubahan pada fisik makhluk hidup yaitu sesuai dengan kebutuhan, tidak merubah fungsinya dan tidak merugikan pihak lain (kemaslahatan) dalam praktek transplantasi organ tubuh. Ketiganya hanya dapat dilihat dari pandangan diri sendiri, antara kebutuhan atau tidak, apakah dapat menimbulkan kerugian atau tidak teruma auntuk diri sendiri, serta tidak sampai pada batasan merubah fungsi orang tubuh yang dirubah tersebut.

\section{DAFTAR PUSTAKA}

Adawiyah, Rabiatul dkk, Pemutihan Kulit Dalam Prinsip Mengubah Ciptaan Allah SWT, Fikiran Masyarakat, Vol. 6, No. 2, 2018.

Al Bagawiy, Abu Muhammad al-Husain bin Mas'ud, Ma'alim At Tanzil, jilid 2, Cet.IV, (t.tp: Dar Thibah li an-Nasyr wa at-Tawzi'), 1997.

Al-Bagdadi, Abu al-Fadl Syihāb al-Din al-Sayyid Mahmud Afandi al-Alusi, Ruh al Ma'ani fi Tafsir al Qur' an al 'Azim wa al Sab'u al Matsani, Jilid 4 (Beirut: Dar al-Kutub al-ilmiyah, 2001).

Al Hafizh Abu Abdullah Muhammad bin Ismail al-Bukhari, Al Imam, Shahih Bukhari, (Jakarta: Pustaka As-Sunnah), 2010. 
Ari, Shosh Ben, The Changing Attitude of Islam Toward Cosmetic Procedures And Plastic Surgery, Acta Orientalia Academiae Scientiarum Hungaricae, Vol. 66, No. 2, 2013.

Asy-Syafi'i, Syihabuddin Ahmad bin Husain bin Hasan bin Ali bin Yusuf bin Ali bin Arsilan ar-Ramli, Syarh Sunan Abu Dawud Li Ibnu Roslan, Jilid 16, (Damaskus: Darul Falah), 2016.

At-Thabari, Abu Ja'far bin Muhammad, Tafsir at-Thabari, (Jakarta: Pustaka Azzam, 2009), jilid 7.

Dean, Nicola R. dkk, "Defining Cosmetic Surgery", Australian Journal Of Plastic Surgery, Vol. 1. No. 1. 2018.

Ibnu Manzur, Lisan al-Arab, Jilid 15, (Beirut: Darul Kutub Al-Ilmiyah) 2009.

Li, Jun dkk, "Predictive Factors For Cosmetic Surgery: A Hospital-Based Investigation" diakses pada 19 nopember 2019 pada Springer Plus.

Maghfiroh, Nurul dkk, Kajian Yuridis Operasi Plastik Sebagai Ijtihad Dalam Hukum Islam, The 2nd Univercity Research Coloquium 2015.

Rohmah, Lailatu, Kontekstualisasi Hadis Tentang Transplantasi, Jurnal Hikmah, Vol. XIV, No. 2, 2018.

Shihab, M. Quraish, Tafsir Al-Misbah Pesan, Kesan Dan Keserasian al-Qur'an, jilid 2, (Jakarta: Lentera Hati) 2016.

Syamsuddin, Sahiron, Hermeneutika Dan Pengembangan Ulumul Qur'an, (Yogyakarta: Naasea Press), 2017.

Wallace, A. B., "The History And Evolution Of Plastic Surgery", Res Medica Journal of The Royal Medical Society, Vol. 4, No. 4, 1965. 